\title{
Characterization of HIV-1 envelopes in acutely and chronically infected injection drug users
}

Behzad Etemad', Oscar A Gonzalez', Laura White², Oliver Laeyendecker ${ }^{3,4}$, Gregory D Kirk ${ }^{3,5}$, Shruti Mehta ${ }^{3,5}$ and Manish Sagar ${ }^{1 *}$

\begin{abstract}
Background: Mucosally acquired human immunodeficiency virus type 1 (HIV-1) infection results from a limited number of variants, and these infecting strains potentially have unique properties, such as increased susceptibility to entry blockers, relative interferon-alpha (IFN-a) resistance, and replication differences in some primary cells. There is no data about the phenotypic properties of HIV-1 envelope variants found early after acquisition among subjects infected through injection drug use (IDU). For the first time, we compared the characteristics of virus envelopes among injection drug users sampled prior to seroconversion (HIV RNA+/Ab-), within 1 year (early), and more than 2 years (chronic) after estimated acquisition.
\end{abstract}

Results: Virus envelopes from 7 HIV RNA+/Ab- subjects possessed lower genetic diversity and divergence compared to 7 unrelated individuals sampled during the chronic phase of disease. Replication competent recombinant viruses incorporating the HIV RNA+/Ab- as compared to the chronic phase envelopes were significantly more sensitive to a CCR5 receptor inhibitor and IFN- $a$ and showed a statistical trend toward greater sensitivity to a fusion blocker. The early as compared to chronic infection envelopes also demonstrated a statistical trend or significantly greater sensitivity to CCR5 and fusion inhibitor and IFN- $a$. The HIV RNA+/Ab- as compared to chronic envelope viruses replicated to a lower extent in mature monocyte derived dendritic cells - CD4+ T cell co-cultures, but there were no significant replication differences in other primary cells among the viruses with envelopes from the 3 different stages of infection.

Conclusions: Similar to mucosal acquisition, HIV-1 envelope quasispecies present in injection drug users prior to seroconversion have unique phenotypic properties compared to those circulating during the chronic phase of disease.

Keywords: HIV-1, Envelope, Transmission, Receptor, Replication, Injection drug use, Dendritic cells, Selection, Interferon

\section{Background}

Although injection drug use (IDU) is a relatively common mode of HIV-1 acquisition, only a small number of studies have examined genotypic properties of the viruses found in newly infected subjects who presumably acquired the infection through IDU [1-4]. Furthermore, phenotypic characteristics of the viruses circulating in these newly infected individuals have not been examined in detail. Transmitted-founder (T/F) or viruses isolated prior to seroconversion have been most extensively studied in individuals who acquired their infection through sexual contact [5-14]. There are significant differences in

\footnotetext{
* Correspondence: msagar@bu.edu

'Boston University School of Medicine, Boston, MA, USA

Full list of author information is available at the end of the article
}

acquiring HIV-1 sexually compared to from IDU. Sexual acquisition is relatively inefficient potentially because the virus must cross a mucosal barrier to infect early target cells at the site of invasion prior to establishing a systemic infection. On the other hand, the estimated frequency of transmission is much higher during IDU compared to the various modes of sexual contact, potentially because infectious virus often has direct access to bloodstream susceptible cells [15]. Sexual HIV-1 acquisition is also associated with a selective bottleneck during transmission [1,4,6-9,16-20]. Only a limited number of variants, sometimes only one, successfully establish an infection in a naïve host even though the transmitting partner harbors a diverse range of viruses. Interestingly, we and others have shown that HIV-1 infected injection drug users also often harbor a relatively limited number of viruses early in 
infection, although a larger number of variants often infect injection drug users compared to those who acquired the virus through sexual contact [1-3]. Because greater initial viral diversity is associated with faster disease progression [17], it is possible that characteristics of the infecting quasispecies are likely different among injection drug users compared to individuals who acquire the virus through sexual contact.

Diverse lines of evidence suggest that the observed bottleneck during sexual transmission occurs as a consequence of active selection rather than a stochastic process. Infecting viruses are often more closely related to HIV-1 variants found earlier during infection (termed ancestral strains) as compared to those circulating near the estimated time of transmission in the transmitting partner, which suggests the preferential selection of archived rather than contemporaneous strains during transmission [5,20-23]. In agreement with this genotypic observation, infecting viruses generally have smaller and less glycosylated envelopes compared to the dominant strains in the transmitting partner or variants isolated during chronic infection [20,24]. Because viruses expand their envelope length and increase the number of predicted glycosylation sites over the course of infection, this argues that viruses with genotypes closer to ancestral strains are favored for transmission [13,24-27]. The observation that newly infected subjects are predominantly infected with viruses that use the CCR5 receptor (termed R5) even though the transmitting partners often harbor both R5 and variants that can only use the CXCR4 receptor (termed X4) further suggests active selection during transmission $[5,8,11,12,14,20,21,28,29]$. In addition, viruses found during the chronic phase as compared to those circulating early after acquisition have decreased sensitivity to CCR5 inhibitors, suggesting they have an enhanced ability to use low levels of or structurally variant forms of the CCR5 receptor [30-34]. Together, this implies that chronic stage viruses that can only utilize the CXCR4 receptor or infect cells that have low levels or different conformations of the CCR5 receptor are not favored for transmission. Furthermore, recent studies demonstrate both that $\mathrm{T} / \mathrm{F}$ as compared to chronic infection strains replicate to higher titers in the presence of IFN- $\alpha$ and viruses become more susceptible to IFN- $\alpha$ within 1 year after acquisition $[11,35]$. This implies that chronic stage variants with decreased replication in the presence of IFN- $\alpha$ have a disadvantage during transmission. In aggregate, these findings strongly suggest that the transmitted viruses with genotypic and phenotypic characteristics similar to ancestral strains have preferential advantage in establishing a systemic infection in a naïve host. It remains unclear if similar active selection occurs among viruses acquired through IDU as observed during sexual acquisition. In this study, we compared properties of the envelope quasispecies isolated from injection drug users sampled prior to HIV-1 seroconversion to those present over the first 2 to 3 years after acquisition.

\section{Results}

Subjects

We previously compared some characteristics among the virus envelope swarm present within 1 year (early) to those present around $2-3$ years (chronic) after estimated seroconversion [34]. We wished to compare more envelope characteristics among these participants to unrelated subjects who also reported IDU and who were sampled prior to seroconversion (HIV RNA+/Ab-). None of the subjects had received any anti-retroviral treatment. Among the HIV RNA+/Ab- subjects, we chose to examine envelope quasispecies as opposed to the predicted $\mathrm{T} / \mathrm{F}$ strains because injection drug users have been shown to acquire a greater number of variants [1-3]. As previously argued [36], we presumed that the combination of virus envelopes within a swarm would better recapitulate the envelope phenotype of the infecting virus population. Thus, we did not isolate presumed $\mathrm{T} / \mathrm{F}$ strains from the HIV RNA+/Ab- subjects. In addition, we did not select specific envelopes from the early and chronic infection samples because this selection would bias the study. As a result, we used the same envelope isolation and virus construction methodology among the HIV RNA+/Ab- as used previously for the early and chronic infection group [34]. We successfully amplified full-length envelopes from 8 of 10 cohort subjects retrospectively confirmed as sampled prior to HIV-1 seroconversion. We could not amplify envelopes from the remaining samples with various different primer sets even though they contained relatively high plasma virus levels (25,873 and 98,533 copies/ml). Inability to amplify HIV-1 from some individuals even though they contain high virus levels is similar to previous studies from our group and others potentially suggesting sample properties prevents full-length envelope recovery $[5,17,37]$. Pooled amplification products from 4 independent PCRs were placed within a NL4-3 backbone, and virus stocks were generated using previous methods shown to reconstitute the viral quasispecies present in the original sample $[30,38,39]$. Indeed in our previous study, we showed that virus stocks contained similar level of genetic diversity and types of envelope variants as that present in the original sample [5]. Seven of the 8 envelope quasispecies incorporated within NL4-3 yielded infectious virus stocks. We compared the envelope characteristics from these 7 HIV RNA+/Ab- subjects to those from 7 longitudinally sampled individuals whose pool of amplified envelopes incorporated into NL4-3 also yielded infectious virus stocks (Table 1). All subjects, except A4 were hepatitis $\mathrm{C}$ virus (HCV) antibody positive prior to the time of estimated HIV-1 seroconversion. This is a strong marker 
Table 1 Subject characteristics

\begin{tabular}{|c|c|c|c|c|c|}
\hline Subject & Estimated PI (months) ${ }^{1}$ & Plasma virus level & $\mathrm{CCR5}^{2}$ & $\mathrm{CXCR}^{3}$ & Tropism $^{4}$ \\
\hline$\overline{A 31}$ & $\mathrm{Ab}-/ \mathrm{VL}+$ & 154,381 & 12.7 & 13.83 & $\mathrm{R} 5 / \mathrm{X} 4$ \\
\hline A33 & $\mathrm{Ab}-/ \mathrm{VL}+$ & $1,031,929$ & 9.7 & $<0.03$ & R5 \\
\hline A38 & $\mathrm{Ab}-/ \mathrm{VL}+$ & 31,174 & 10.8 & $<0.03$ & R5 \\
\hline A40 & $\mathrm{Ab}-/ \mathrm{VL}+$ & 14,422 & 14.9 & $<0.03$ & R5 \\
\hline A41 & $\mathrm{Ab}-/ \mathrm{VL}+$ & $1,289,549$ & 13.3 & $<0.03$ & R5 \\
\hline A42 & $\mathrm{Ab}-/ \mathrm{VL}+$ & $2,285,517$ & 12.6 & $<0.03$ & R5 \\
\hline A43 & $\mathrm{Ab}-/ \mathrm{VL}+$ & 499,713 & 12.3 & $<0.03$ & R5 \\
\hline $\mathrm{A} 2$ & 3.0 & 85,439 & 11.5 & $<0.03$ & R5 \\
\hline A4 & 5.0 & $2,158,680$ & 1.9 & 14.3 & $\mathrm{R} 5 / \mathrm{X} 4$ \\
\hline A5 & 4.1 & 279,745 & 8.7 & $<0.03$ & R5 \\
\hline A17 & 4.9 & 40,634 & 14.6 & $<0.03$ & R5 \\
\hline A18 & 3.2 & 188,258 & 12.1 & $<0.03$ & R5 \\
\hline A23 & 4.9 & 56,189 & 10.6 & $<0.03$ & R5 \\
\hline A27 & 4.1 & 152,472 & 10.4 & $<0.03$ & R5 \\
\hline $\mathrm{A} 2$ & 21.4 & 30,996 & 19.1 & $<0.03$ & R5 \\
\hline A4 & 24.5 & 79,094 & 0.3 & 12.2 & $\mathrm{R} 5 / \mathrm{X} 4$ \\
\hline A5 & 27.2 & 137,661 & 11.1 & $<0.03$ & R5 \\
\hline A17 & 20.9 & 20,995 & 13.0 & $<0.03$ & R5 \\
\hline A18 & 27 & 12,299 & 11.6 & $<0.03$ & R5 \\
\hline A23 & 27.7 & 79,490 & 12.1 & $<0.03$ & R5 \\
\hline A27 & 27.1 & 17,668 & 9.8 & 11.91 & $\mathrm{R} 5 / \mathrm{X} 4$ \\
\hline
\end{tabular}

${ }^{1}$ Interval in months from the estimated date of seroconversion to the day of sample collection. Ab-/VL+: Sampled prior to seroconversion.

${ }^{2} \mathrm{P} 24(\mathrm{ug} / \mathrm{ml})$ from $\mathrm{U} 87 / \mathrm{CD} 4 / \mathrm{CCR} 5$ cells at day 4 post-infection.

${ }^{3} \mathrm{P} 24$ (ug/ml) from U87/CD4/CXCR4 cells at day 4 post-infection.

${ }^{4}$ Tropism as determined on U87/CD4+/CCR5 and U87/CD4+/CXCR4 cells.

for IDU. Indeed, 11 of the 14 subjects, including A4, reported injecting drugs in the 6 months prior to estimated HIV-1 seroconversion.

As expected, the HIV RNA+/Ab- (median $\log _{10}$ plasma virus copies per $\mathrm{ml} 5.7$, range $4.2-6.4$ ) compared to the chronic (median $\log _{10} 4.5$ copies/ml, range 4.1 - 5.1, $\mathrm{p}=0.05$ ) samples had higher plasma virus levels. Plasma virus levels in the HIV-1 RNA+/Ab- as compared to the early (median $\log _{10} 5.2$ copies $/ \mathrm{ml}$, range $4.6-6.3$, $\mathrm{p}=0.6$ ) samples were not statistically different. Longitudinal plasma virus levels significantly decreased from early in disease to the chronic phase of infection (median $\log _{10}$ plasma virus copies per $\mathrm{ml}$ difference 0.4 , range $-0.1-1.4$, $\mathrm{p}=0.04)$. These plasma virus level differences followed the expected pattern of high virus replication immediately after acquisition and a decrease to a viral set point during the chronic phase of disease.

\section{Envelope sequences}

Unlike previous studies of individuals presumably infected through IDU, the primary goal of this study was not to examine genotypic features of the HIV-1 envelopes present at various times during infection $[2,3]$.
Even though bulk PCR cloning as compared to single genome amplification (SGA) potentially introduces polymerase induced recombination artifacts, we examined 12 clonal sequences per sample because we compared overall virus population characteristics rather than individual genomes $[6,40]$. Phlyogenetic analysis confirmed that all subjects harbored subtype B HIV-1, and all early and chronic infection sequences were related ruling out contamination and HIV-1 superinfection (Figure 1). Envelopes from individuals sampled prior to seroconversion had lower genetic diversity (median 0.001, range 0.0004 - 0.01) compared to the chronic (median 0.007, range $0.001-0.02, \mathrm{p}=0.05$ ) group, but there were non-significant differences compared to envelopes from early (median 0.006, range $0.0008-0.008, \mathrm{p}=0.2)$ infection. The HIV RNA+/Abenvelopes (median 0.001, range $0.0005-0.01$ ) were also less divergent than the chronic (median 0.007, range $0.001-0.02, \mathrm{p}=0.05$ ) and not statistically significantly different compared to the early (median 0.004, range $0.0007-0.02, \mathrm{p}=0.2$ ) infection genotypes. Similar to previous publications that examined HIV-1 subtype B envelope genes by the bulk PCR cloning methodology, the 3 groups did not have significant differences in 


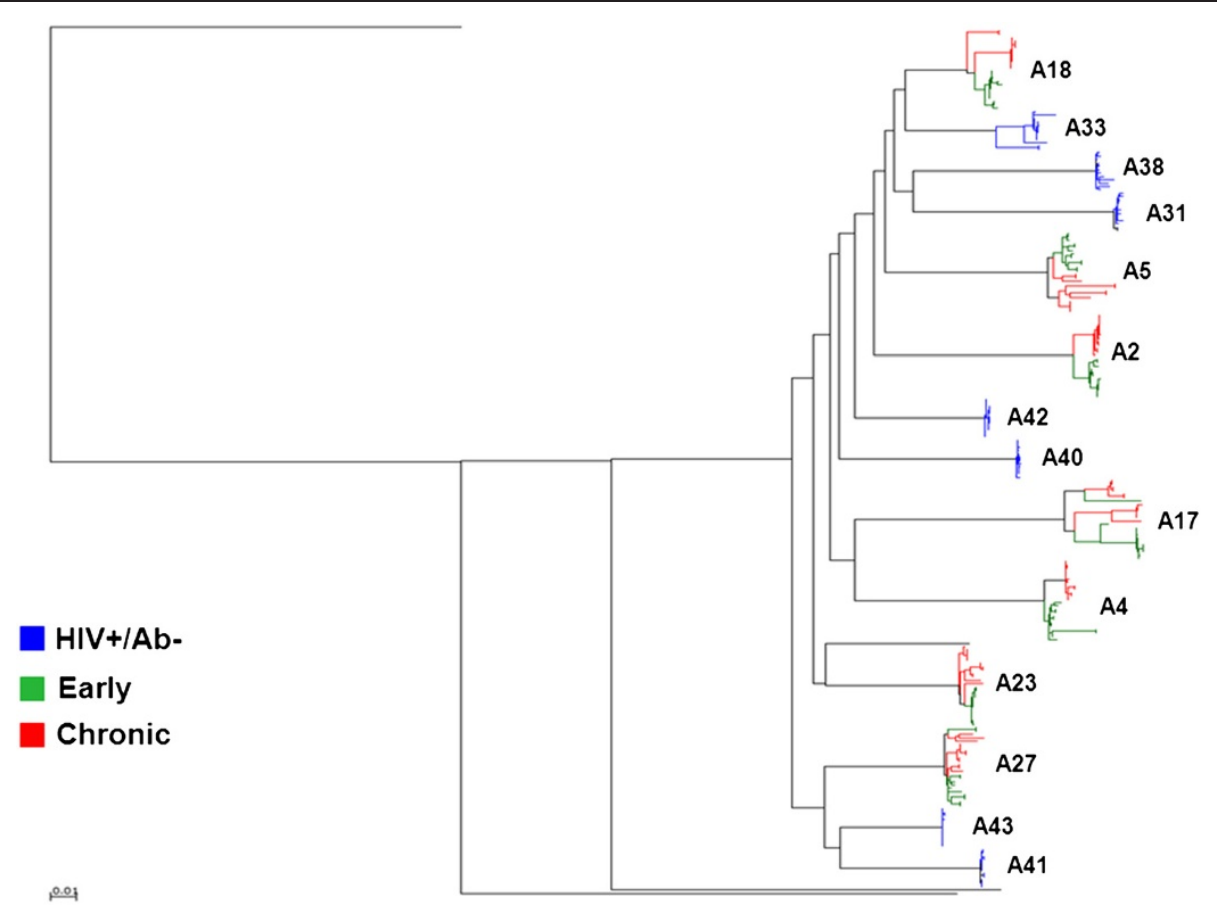

Figure 1 The HIV RNA+/Ab- envelopes are not related to the virologically linked early and chronic infection variants. Full-length HIV-1 envelope sequences were aligned with subtype reference sequences from the Los Alamos database using Clustal X. Maximum likelihood phylogenies were generated using Paup with parameters from FindModel best fit evolutionary model as described previously [21]. Subject IDs are noted with the different color nodes representing sequences from the 3 groups.

envelope variable loop length or number of predicated aspargine linked glycosylation sites [24,27].

\section{Replication competent viruses}

Bulk PCR envelope products were incorporated into a NL4-3 HIV-1 backbone to generate replication competent recombinant viruses using previously described methods [34]. Because we were interested in comparing the properties of the quasispecies at various times after infection, we examined envelope pools as opposed to individual SGA amplified envelopes. To confirm that potential polymerase induced recombination during bulk PCR did not generate novel phenotypes that did not exist in the original sample, we compared virus stocks containing a pool of envelopes generated using either SGA or bulk PCR. In 6 cases, the virus stocks with the bulk PCR and SGA envelope pools demonstrated equivalent infectivity and replication kinetics (Additional file 1: Figure S1). This suggests that the method for generating envelope pools did not have a significant influence on their in-vitro phenotypic properties.

\section{Receptor usage}

In-vitro, the majority of HIV RNA+/Ab-, early and chronic infection envelopes used the CCR5 receptor and failed to employ the CXCR4 co-receptor (Table 1). We assessed sensitivity to receptor and fusion inhibitors as a way to examine if the envelopes from the various stages of infection had differences in their fusion capacity or ability to use low levels of CD4 and CCR5. We have previously shown that these inhibitor sensitivity assays clearly distinguish envelopes that require high versus low receptor levels for host cell entry [30]. The HIV RNA+/Ab(median $\mathrm{IC}_{50} 5.6$, range $1.3-18.1 \mathrm{ug} / \mathrm{ml}$ ) as compared to the early (median $\mathrm{IC}_{50} 3.8$, range $2.9-8.9 \mathrm{ug} / \mathrm{ml}, \mathrm{p}=0.5$ ) and chronic (median $\mathrm{IC}_{50} 7.0$, range $4.9-9.2 \mathrm{ug} / \mathrm{ml}$, $\mathrm{p}=0.6$ ) envelopes showed no significant difference in their sensitivity to a monoclonal anti-CD4 antibody (Figure 2A). Paired analysis showed that the early as compared to the chronic infection envelopes were marginally more sensitive to the monoclonal anti-CD4 antibody (median $\mathrm{IC}_{50}$ difference 2.5 , range $-0.3-6.3 \mathrm{ug} / \mathrm{ml}$, $\mathrm{p}=0.05)$.

CCR5 usage efficiency was assessed by estimating sensitivity to the CCR 5 inhibitor, Maraviroc. Envelopes with documented ability to use the CXCR4 receptor were omitted from this analysis. At the highest Maraviroc concentration tested $(50 \mathrm{nM})$, all tested envelopes showed greater than 95\% inhibition suggesting there were no resistant envelopes as observed in previous studies [33,41]. The HIV RNA+/Ab- envelopes (median $\mathrm{IC}_{50}$ 3.2, range $0.8-6.3 \mathrm{nM}$ ) were more sensitive to Maraviroc compared to the chronic (median $\mathrm{IC}_{50} 4.5$, range $4.3-8.4 \mathrm{nM}$, $\mathrm{p}=0.03$ ) but not early (median $\mathrm{IC}_{50} 1.8$, range $4.3-8.4 \mathrm{nM}$, 

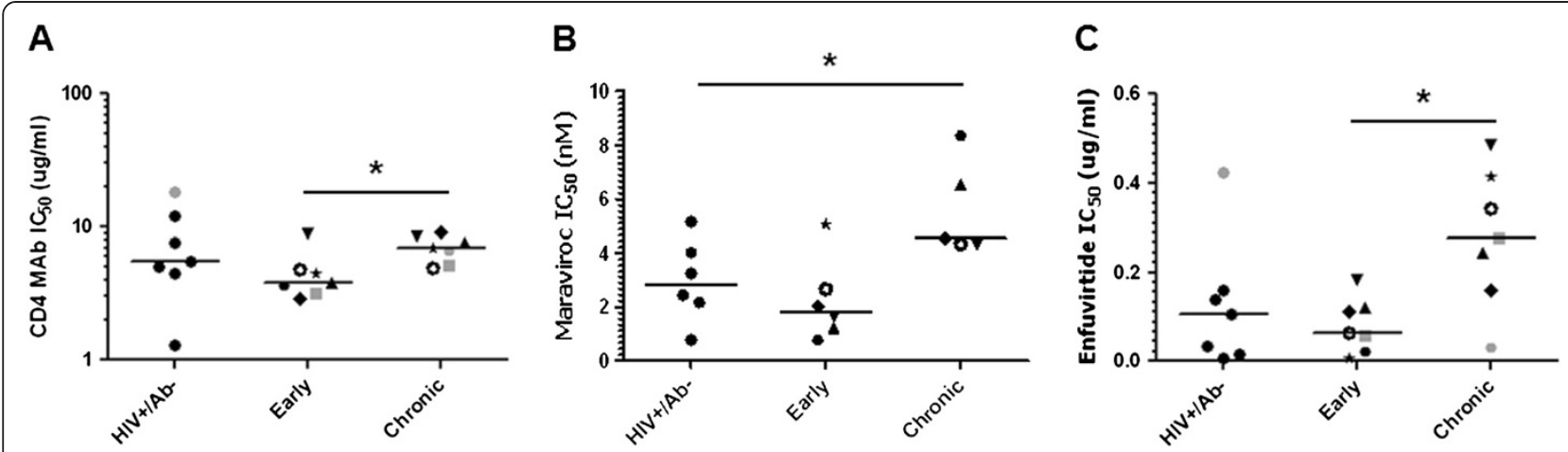

Figure 2 The HIV RNA+/Ab- envelopes have greater sensitivity to CCR5 and fusion inhibitors. Scatter plots show IC 50 S to $C D 4$ antibody (A), Maraviroc (B), and Enfuvirtide (C) with a line denoting the median. Each individual symbol represents a subject's mean from a minimum of 3 independent experiments. Circles denote the estimates for the HIV RNA+/Ab- subjects. The longitudinal sampling is denoted by a unique symbol

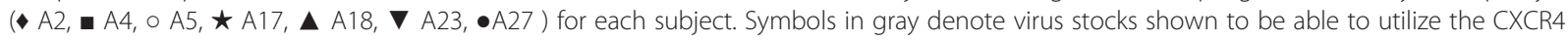
receptor. Significant differences $(p \leq 0.05)$ are indicated with a star in the graphs. Four envelope quasispecies with the documented ability to use the CXCR4 receptor were omitted from the examination of Maraviroc sensitivity.

$\mathrm{p}=0.3$ ) variants (Figure $2 \mathrm{~B}$ ). Early envelope viruses also showed a trend toward increased Maraviroc sensitivity compared to the paired chronic infection variants (median difference 2.7 , range $1.7-7.6 \mathrm{nM}, \mathrm{p}=0.06$ ). This suggests that envelopes prior to seroconversion as compared to those present at the chronic phase require higher CCR5 receptor levels for cell entry.

Sensitivity to Enfuvirtide was used to assess fusion capacity. There was a trend that HIV RNA+/Ab- envelopes (median 0.1, range $0.01-0.4 \mathrm{ug} / \mathrm{ml}$ ) were more sensitive compared to the chronic (median 0.3, range $0.03-0.5 \mathrm{ug} / \mathrm{ml}, \mathrm{p}=0.07$ ) but not the early variants (median 0.07, range $0.006-0.2 \mathrm{ug} / \mathrm{ml}, \mathrm{p}=0.9$ ) (Figure 2C). The early envelopes were significantly more sensitive to Enfuvirtide compared to the longitudinally isolated chronic variants (median difference 0.2, range $0.01-0.4$ $\mathrm{ug} / \mathrm{ml}, \mathrm{p}=0.01$ ). Similar to the Maraviroc findings, early phase infection envelopes have the greatest susceptibility, and pre-seroconversion as compared to the chronic phase envelopes have higher Enfuviritide sensitivity.

\section{Replication in primary cells}

To assess replication, we monitored both p24 antigen and infectious virus concentration as assessed on TZM-bl cells in the culture supernatants post infection. The p24 antigen and infectious virus concentration curves over time displayed similar morphology among the diverse viruses. The area under the replication curve (AUC) from the p24 antigen measurements was highly correlated to the AUC from the infectious virus estimation ( $\rho=0.7, p=0.002$, Spearman rank correlation) suggesting that either method could be used to follow virus production (Additional file 1: Figure S2).

Replication in primary cell cultures was used to examine if envelope quasispecies from different phases of infection confer varying replication capacity. Replication was examined in CD4+ $\mathrm{T}$ cells from 4 different individual donors. There was large replication variation between the different blood donor's cells (Additional file 1: Figure S3). In addition, a virus stock that produced the highest area under the replication curve (AUC) in CD4+ T cells from 1 donor did not always yield the highest AUC in CD4+ T cells from other donors. Thus, different blood donation volunteers CD4+ T cells supported replication to varying levels in both individual virus stocks and among the entire group. As a result, we chose to analyze replication both individually in primary cells from 1 donor and in aggregate among primary cells from different donors. In cells from a majority of donors, the HIV RNA+/Ab- envelope viruses replicated to greater extent compared to the viruses with early and chronic infection envelopes, but these differences were not statistically significant in any of the donors individually (Figure 3 ). In aggregate, the HIV $\mathrm{RNA}+/ \mathrm{Ab}$ - envelopes also did not have statistically significant replication difference compared to the early (log estimated AUC difference 0.6, 95\% confidence interval (CI) $-0.1-1.3, \mathrm{p}=0.07$ ) or chronic (log AUC difference $0.1,95 \%$ CI $-0.7-0.8, \mathrm{p}=0.7)$ group. The early infection envelope viruses did not have significantly different replication AUC compared to the chronic infection envelope variants in the CD4+ T cells, both in aggregate (log AUC difference $0.3,95 \% \mathrm{CI}-1.1-1.6, \mathrm{p}=0.6$ ) or when the cells from different donors were analyzed separately.

Dendritic cells (DCs) have been proposed to play an important role in HIV-1 transmission because they can efficiently capture viruses and transmit them to $\mathrm{CD} 4+\mathrm{T}$ cells, which significantly enhances virus replication [42-44]. We examined if the envelope quasispecies from different phases of infection confer differences in ability to utilize monocyte derived DCs (MDDCs). Again, donor 

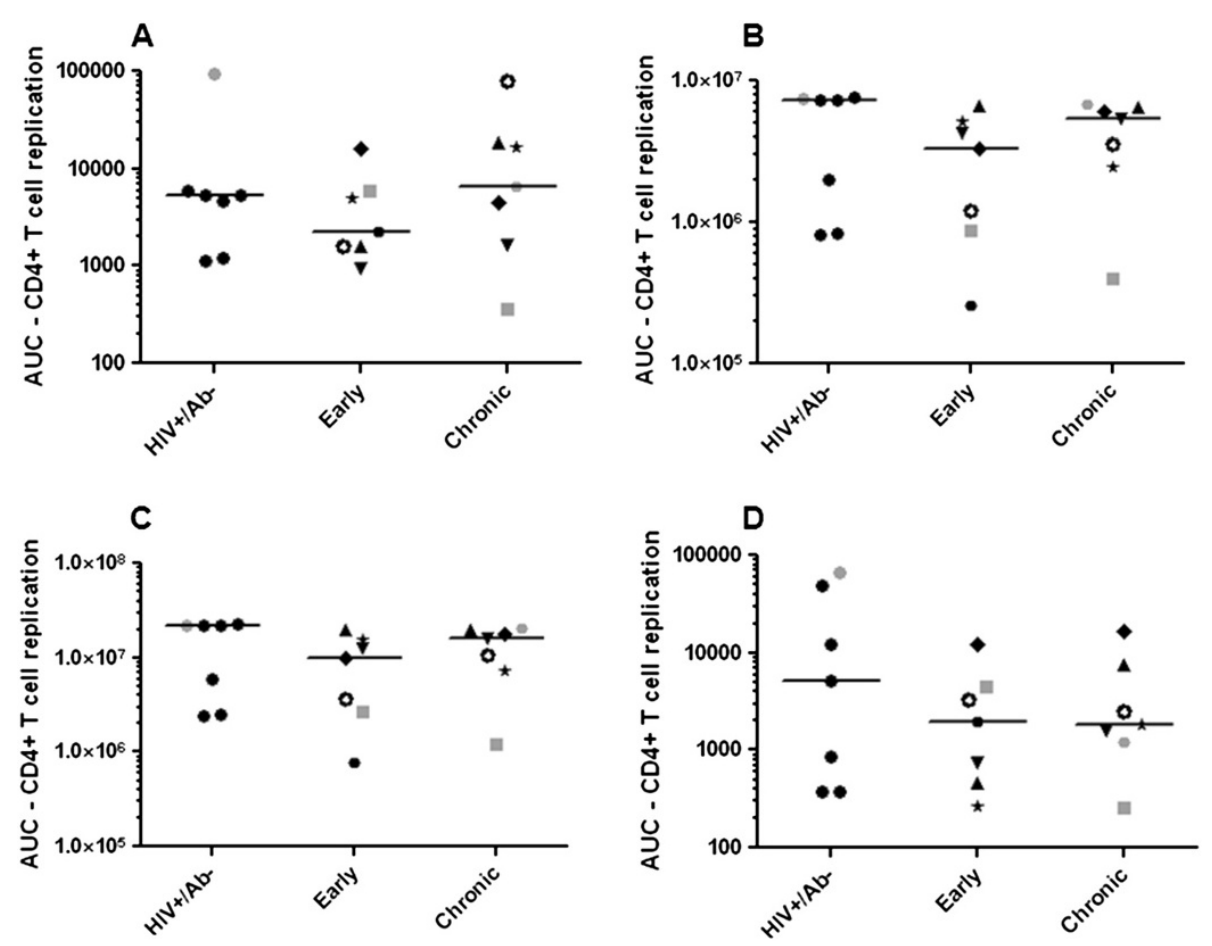

Figure 3 Viruses with envelopes from different phases of infection demonstrate similar replication capacity in CD4+ T cells. Scatter plots show replication area under the curve (AUC) in activated CD4+ T cells from 4 different HIV-1 seronegative donors (A-D). The AUC was calculated over 10 days post infection. Each individual symbol represents a subject's AUC. Similar to Figure 2, in the early and chronic group unique symbols are used to show the longitudinal changes within an injection drug user. In each scatterplot, the lines denote the median. Symbols in gray denote virus stocks shown to be able to utilize the CXCR4 receptor.

cell variability was also evident in MDDCs from different donors (Additional file 1: Figures S4 and S5). In 1 donor's mature MDDCs - CD4+ T cell co-culture, the HIV RNA+/Ab- replicated less efficiently as compared to the chronic viruses (Figure 4). In aggregate, the HIV $\mathrm{RNA}+/ \mathrm{Ab}$ - envelope viruses had significantly lower replication AUC compared to the chronic (log AUC difference $-1.3,95 \% \mathrm{CI}-2.6-0.002, \mathrm{p}=0.03$ ) but nonsignificant differences compared to the early (log AUC difference $-0.7,95 \% \mathrm{CI}-2.1-0.6, \mathrm{p}=0.3)$ infection envelopes in mature MDDC - CD4+ $\mathrm{T}$ cell co-cultures. There was, however, no statistical trend or significant difference among the early versus chronic envelopes ( $\log$ AUC difference 1.5, 95\% CI $-1.3-4.2, \mathrm{p}=0.3$ ).

The HIV RNA+/Ab- envelopes also showed lower replication AUC compared to the early (log AUC difference $-1.0,95 \% \mathrm{CI}-2.3-0.3, \mathrm{p}=0.1$ ) and chronic variants (log AUC difference -0.4, 95\% CI - $1.5-0.9$, $\mathrm{p}=0.6)$ in immature MDDC $-\mathrm{CD} 4+\mathrm{T}$ cell co-cultures, but the differences were not statistically significant. In aggregate, the early as compared to the chronic infection envelope viruses also did not have significant replication differences in immature MDDC - CD4+ T cell cocultures ( $\log$ AUC difference $-3.1,95 \%$ CI -7.3 - 0.7, $\mathrm{p}=0.1$.

\section{Gut homing receptor usage}

Early after HIV-1 acquisition, high level virus replication occurs in gut associated lymphoid tissue (GALT) [45]. The gut homing receptor, $\alpha 4 \beta 7$, potentially facilitates virus migration from the site of acquisition to the GALT [46-48]. In our previous studies, we showed binding and replication augmentation in cells with increased as compared to normal $\alpha 4 \beta 7$ expression among viruses with known $\alpha 4 \beta 7$ reactivity, such as HIV-1 $1_{\text {SF162 }}$ and HIV-1 $1_{\text {Bal }}$ [49]. In addition, previous studies from our group and others have shown that $\alpha 4 \beta 7$ inhibitors often fail to prevent virus replication in and binding to cells expressing high levels of $\alpha 4 \beta 7[12,49]$. Thus, we used similar methods to examine if envelope quasispecies from the 3 phases of infection had replication and binding differences in retinoic acid (RA) stimulated $\mathrm{CD} 4+$ and $\mathrm{CD} 8+\mathrm{T}$ cells with flow cytometry confirmed high levels of $\alpha 4 \beta 7$ receptor respectively in the absence of any inhibitors. The HIV RNA+/Ab- envelopes showed no significant replication difference compared to the early (log RLU difference $-0.5,95 \% \mathrm{CI}-1.3-0.2, \mathrm{p}=0.1$ ) or chronic ( $\log$ RLU difference $0.3,95 \% \mathrm{CI}-0.6-1.2, \mathrm{p}=0.5$ ) envelopes in $\alpha 4 \beta 7$ high CD4+ $\mathrm{T}$ cells (Figure $5 \mathrm{~A}-\mathrm{D}$ ). In addition, replication was not significantly different in the $\alpha 4 \beta 7$ high CD4+ T cells in any of the 4 donors when 


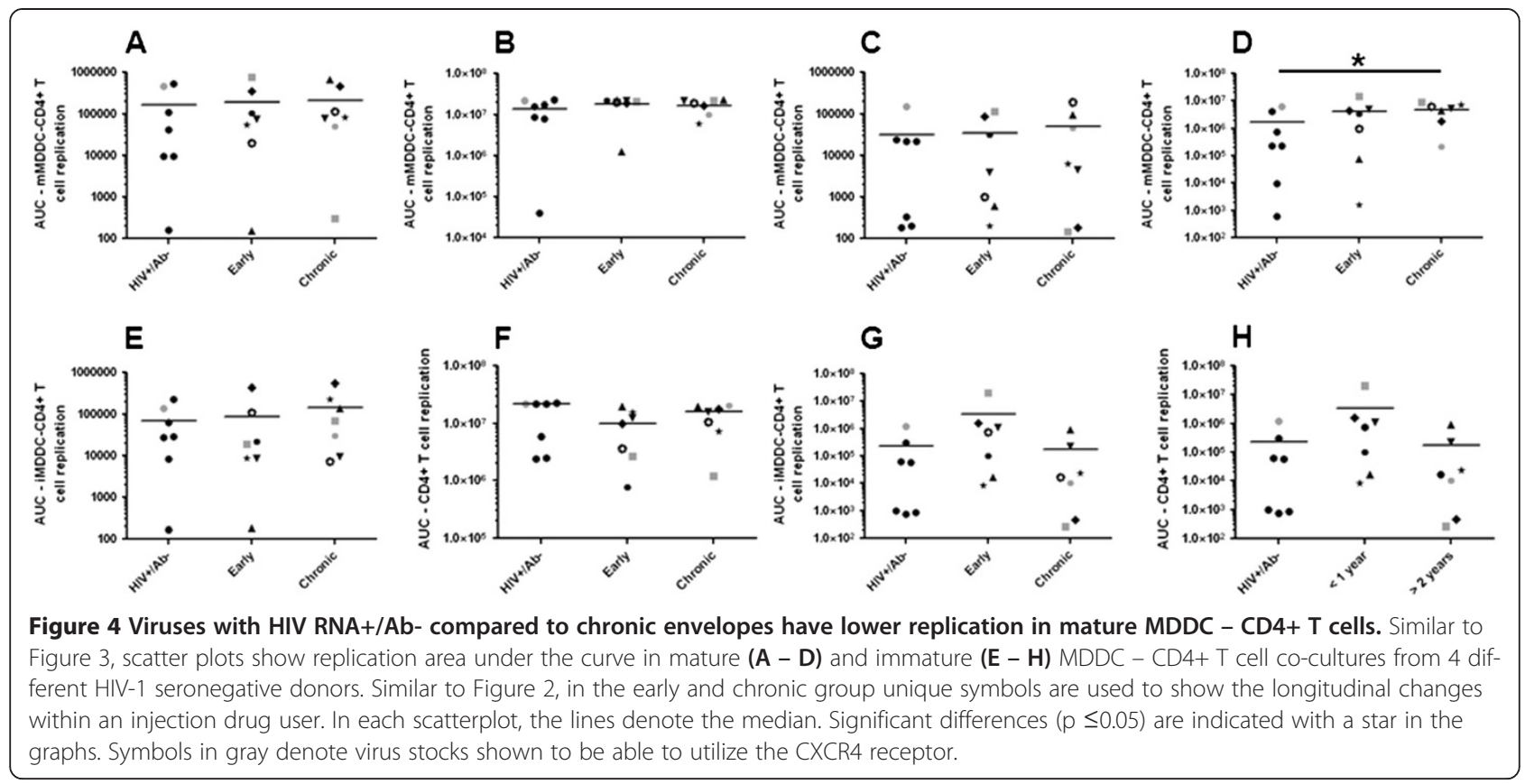

analyzed separately. Individually and in aggregate, the early as compared to the chronic infection envelope viruses also did not have significant replication differences in $\alpha 4 \beta 7$ high CD4+ T cells (log RLU difference 1.0, 95\% CI $-0.2-2.8, \mathrm{p}=0.4$ ).

The HIV RNA+/Ab- as compared to the chronic envelope viruses showed significantly greater binding to $\alpha 4 \beta 7$ high CD8+ T cells in 1 of the 4 donors (Figure 5E - H).
In aggregate, the HIV RNA+/Ab- envelopes also showed significantly greater binding compared to the chronic ( $\log$ RNA copy difference 1.0, 95\% CI $0.02-1.9, \mathrm{p}=0.03$ ) but not the early (log RNA copy difference 0.3 , 95\% $\mathrm{CI}-0.3-1.0, \mathrm{p}=0.3)$ envelopes. The early as compared to the chronic infection envelope viruses did not have significant binding differences to $\alpha 4 \beta 7$ high CD8+ T cells $(\log$ RNA copy difference $0.6,95 \%$ CI $-0.01-0.6$,

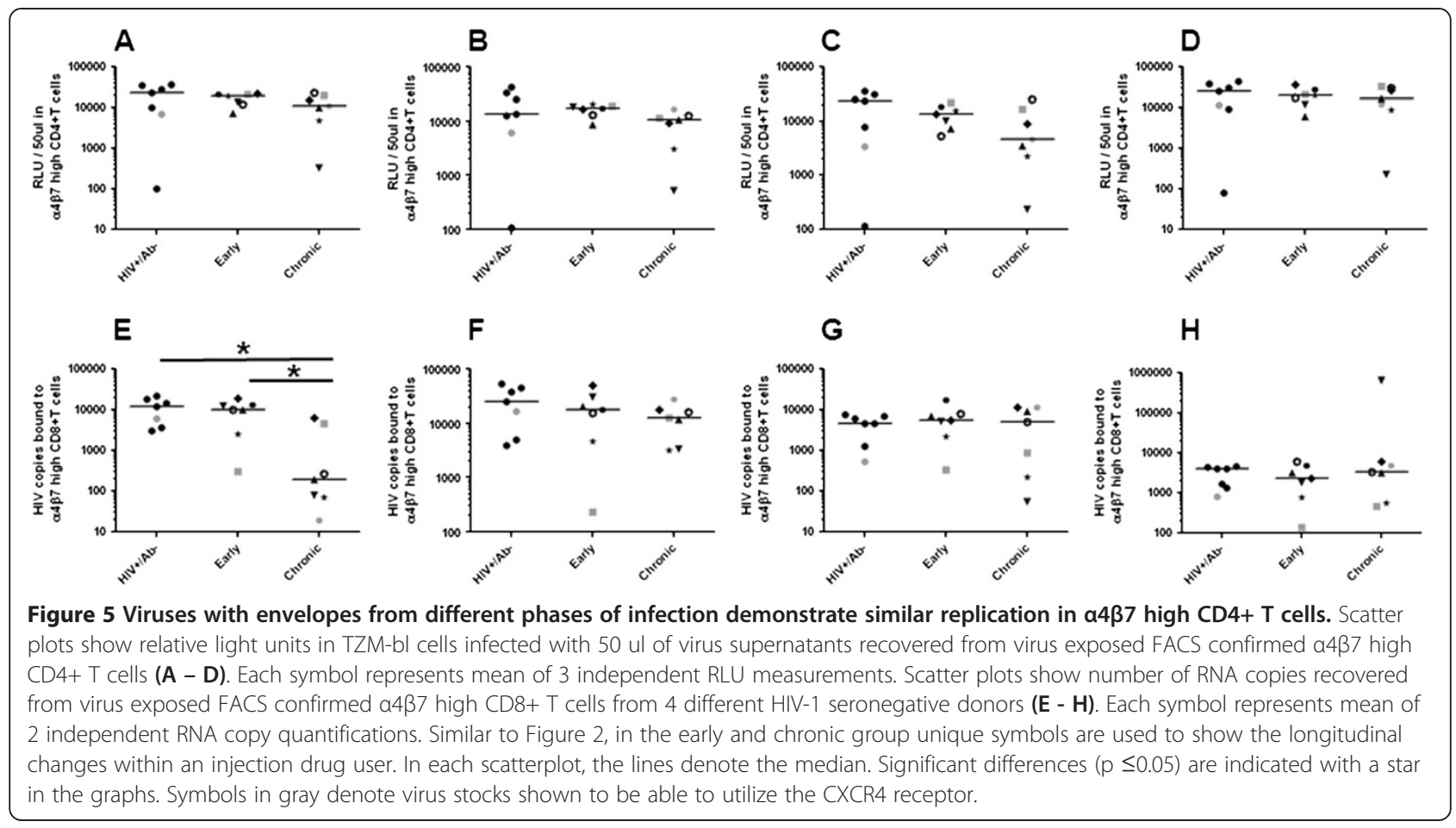


$\mathrm{p}=0.2$ ), although significant difference was observed in 1 donor's cells.

\section{Susceptibility to IFN-a}

In the SIV/macaque model, it has been shown that exposure to virus elicits a strong anti-viral response, such as elevated levels of IFN- $\alpha$ [50]. These anti-viral responses induce target cells, such as activated CD4+ $\mathrm{T}$ cells, to the site of invasion and also inhibit virus replication. Recent studies suggest that HIV-1 variants able to replicate in the presence of high interferon levels are potentially favored to establish an infection in a naïve host $[11,35]$. We examined if the virus stocks with HIV RNA+/Ab- envelope quasispecies demonstrated greater IFN- $\alpha$ resistance compared to the early and chronic infection envelope viruses (Additional file 1: Figure S6). Surprisingly, the HIV RNA+/Ab- envelope viruses demonstrated significantly lower resistance compared to the chronic group in CD4+ T cells from 2 of the 4 donors (Figure 6). In aggregate, the HIV RNA+/Ab- envelope viruses had a statistically significant 0.7 log lower $\%$ IFN- $\alpha$ resistance compared to the chronic group (95\% CI $-1.23--0.15, \mathrm{p}=0.008)$. There was also a statistical trend that the HIV RNA+/Ab- envelopes were more IFN- $\alpha$ sensitive compared to the early group (log \% IFN resistance difference $-0.51,95 \% \mathrm{CI}-0.6-1.2, \mathrm{p}=0.08$ ). In aggregate, the early as compared to chronic infection envelope viruses showed a trend towards greater IFN- $\alpha$ sensitivity $(\log \%$ IFN- $\alpha$ resistance difference $-0.51,95 \%$ $\mathrm{CI}-1.14-0.12, \mathrm{p}=0.1$ ). This suggests that in injection drug users IFN- $\alpha$ resistance increases from the preseroconversion to the early and eventually to the chronic phase of infection.

\section{Discussion}

Even though IDU is a relatively common route for HIV-1 acquisition, there has been limited understanding about the pathogenesis associated with this mode of transmission. In contrast to mucosal acquisition, viruses acquired through IDU do not encounter an epithelial barrier in accessing potential target cells, suggesting that the characteristics of the acquired variants may be different among mucosal versus non-mucosal acquisition. Indeed, previous studies have suggested that injection drug users are often infected with more variants compared to individuals that acquire the virus through heterosexual or homosexual
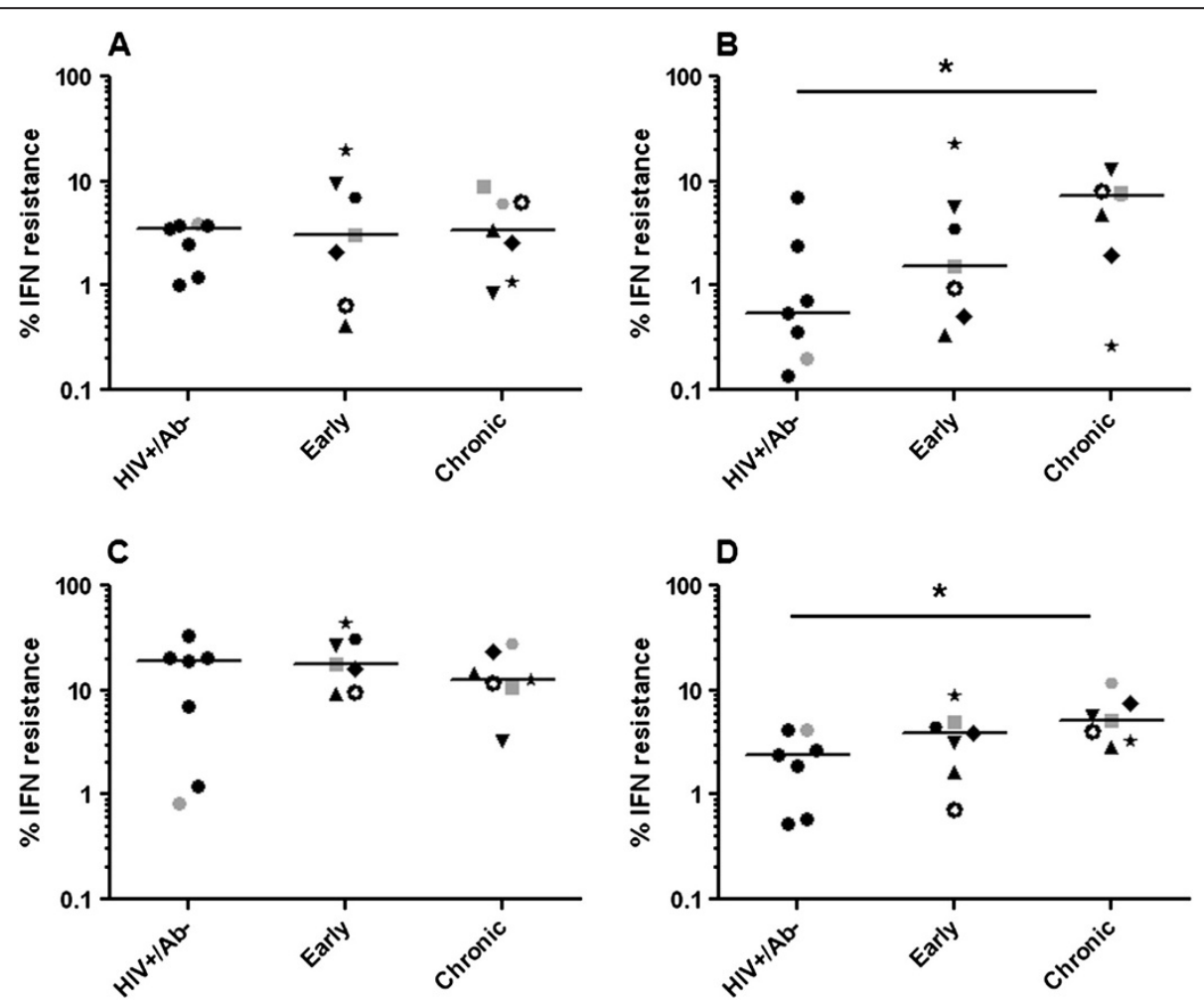

Figure 6 The HIV RNA+/Ab- compared to the chronic envelopes have greater sensitivity to interferon-a. Scatter plots show \% interferon resistance (replication in the presence as compared to the absence of IFN- $\mathbf{a}$ ) in CD4+ T cells from 4 different HIV-1 seronegative donors (A - D). Similar to Figure 2, in the early and chronic group unique symbols are used to show the longitudinal changes within an injection drug user. In each scatterplot, the lines denote the median. Significant differences $(p \leq 0.05)$ are indicated with a star in the graphs. Symbols in gray denote virus stocks shown to be able to utilize the CXCR4 receptor. 
contact [1-3]. In this study, we primarily examined the phenotypic characteristics of the virus envelope quasispecies isolated prior to seroconversion, within an estimated 1 year after acquisition, and during the chronic phase of disease among individuals that presumably acquired HIV-1 through IDU. We found that the envelope quasispecies in HIV RNA+/Ab- compared to the chronically infected subjects were significantly more sensitive to a CCR5 inhibitor and IFN- $\alpha$, and had a trend towards increased susceptibility to Enfuvirtide. Interestingly, the early as compared to the chronic infection envelope quasispecies displayed either a statistical trend or significantly greater sensitivity to Maraviroc, Enfuvirtide, and IFN- $\alpha$. This suggests that injection drug users prior to seroconversion possess unique HIV-1 envelope quasispecies that require high CCR5 receptor levels for host cell entry, have lower fusion capacity, and confer enhanced sensitivity to IFN- $\alpha$. Over the first 2 to 3 years of infection, virus envelope quasispecies evolve the ability to use lower CCR5 levels, have enhanced fusion capacity, and confer decreased IFN- $\alpha$ sensitivity. In aggregate, our findings suggest that viruses with unique envelope characteristics preferentially establish a systemic infection among injection drug users.

Previous studies from our group and others show that the genetic bottleneck during IDU transmission is not as restrictive because the likelihood of acquiring more than a single virus appears higher compared to other routes of HIV-1 acquisition, such as sexual contact [1-3]. Even though the genetic bottleneck is not as restrictive compared to acquisition across a mucosal barrier, the number of infecting variants is still less than what would be typically present in an individual sampled during the early and chronic phases of disease [51]. Smaller number of variants than expected may be circulating in newly infected injection drug users because the virus could be acquired from another individual in the acute phase of infection with relatively limited viral genetic diversity. On the other hand, contaminated needles may only harbor a small number of infectious virions. Because it is logistically difficult to sample the transmission source, it remains unclear if the relatively limited number of variants observed in injection drug users early after acquisition is due to active selection or limited source diversity.

We and others have previously shown that mucosally acquired viruses sampled early after acquisition, including $\mathrm{T} / \mathrm{F}$ viruses, have decreased ability to use low levels of or different conformation of the CCR5 receptor compared to unrelated chronic controls $[30,31,33]$. In this study, we also observed that swarm present prior to seroconversion showed greater sensitivity to Maraviroc compared to the swarm sampled during the chronic phase of disease. Because CCR5 sensitivity is directly correlated to fusion inhibitor susceptibility [52], we also found that the HIV
$\mathrm{RNA}+/ \mathrm{Ab}$ - envelope variants showed a trend toward greater sensitivity to Enfuvirtide compared to the chronic strains $[30,52,53]$. In aggregate, pre-seroconversion variants present in injection drug users and mucosally acquired strains require high levels of CCR5 in an invariant structure to enter host cells. This potentially suggests that similar biological mechanisms favor the ability of relatively CCR5 receptor and fusion inhibitor sensitive variants in establishing a disseminated infection regardless of whether the virus is acquired through IDU or across a mucosal barrier.

Interestingly, we found that envelopes isolated prior to seroconversion conferred greater sensitivity to IFN- $\alpha$ compared to the chronic stage envelopes. Two previous investigations have shown that full-length $\mathrm{T} / \mathrm{F}$ and acute stage viruses are relatively interferon resistant $[11,35]$. This has been used to argue that viruses able to replicate in the presence of high interferon levels at the site of invasion preferentially establish a systemic infection leading to the observed genetic bottleneck during transmission. Interferon resistance may not lead to a genetic restriction in injection drug users because IDU is potentially associated with persistent inflammation [54,55]. Thus, when a naïve individual acquires HIV-1 from a chronically infected injection drug user interferon susceptibility will not present a barrier for most variants in establishing a new systemic infection because viruses circulating in the transmitter may already be relatively interferon resistant. Indeed, a previous study failed to show interferon susceptibility difference between sexually acquired subtype $C \mathrm{~T} / \mathrm{F}$ versus chronic phase variants presumably because the chronically infected transmitters have persistent inflammation [11]. In addition, while the observed differences were statistically significant, it remains unclear if they are clinically meaningful because, in aggregate, the chronic infection viruses were around 2 fold more resistant to interferon compared to the HIV RNA+/Ab- envelope variants. On the other hand, we may have failed to replicate the previous findings because our studies only examined envelope differences, and non-envelope portions of the virus genome may be the genetic determinant for interferon resistance [56].

We also found that the HIV RNA+/Ab- as compared to the chronic envelope viruses replicated less efficiently in mature MDDC - CD4+ T cells. This corroborates other published findings showing that chronic infection envelope quasispecies compared to unrelated sexually acquired $\mathrm{T} / \mathrm{F}$ envelopes demonstrated higher replication in MDDC - CD4+ T cell co-cultures [39]. Furthermore, in our previous study, we found that viruses with envelopes from chronically infected individuals replicated to greater extent in mature MDDC - CD4+ T cells compared to the variants with envelopes from the newly infected heterosexual partner [5]. It should be noted that 
one report suggests that full-length $\mathrm{T} / \mathrm{F}$ as compared to chronic infection controls have greater replication in MDDC - CD4+ T cell co-cultures although significant differences were only observed in subtype $\mathrm{B}$ and not subtype C HIV-1, and the results were based on infections in primary cells from only two different donors [11]. In summary, these results suggest that if dendritic cells play a potential role during initial HIV-1 acquisition then the envelope glycoprotein does not solely dictate which variants successfully establish a new infection.

Our findings failed to reveal replication differences in any of the other primary cells among viruses sampled during the various phases of disease. Even though, HIV $\mathrm{RNA}+/ \mathrm{Ab}$ - as compared to the chronic envelopes demonstrated significantly greater binding to $\alpha 4 \beta 7$ high CD8+ T cells, importantly, there was no significant replication difference in the $\alpha 4 \beta 7$ high CD $4+\mathrm{T}$ cells. Replication as opposed to binding is likely the more important phenotype that determines a virus' fitness for establishing a new infection in a naïve individual. Our previous study of recipient transmitter pairs showed that envelope variants circulating in the chronically infected sexual partner compared to those present in the newly infected subject had higher replication in $\mathrm{CD} 4+\mathrm{T}$ cells with high or normal levels of $\alpha 4 \beta 7$ levels and with and without MDDCs [5]. In contrast, however, another study showed full length sexually acquired T/F strains had greater MDDC binding and trans infection compared to unrelated chronic infection controls [11]. There are likely a number of reasons we may have failed to observe replication differences in the other primary cells among the 3 groups in our study. Even though we detected some significant phenotypic differences, it is likely that we were statistically underpowered to detect small variations because we only examined 7 subjects in each group. Previous studies using relatively similar number of samples per group ( $n=6$ to 11 ) showed significant differences in sensitivity to receptor inhibitors and replication kinetics among sexually acquired envelope variants compared to the unrelated chronic infection strains or variants circulating in the transmitting partner $[5,14,39,57]$. Because selection bottleneck is less restrictive during IDU compared to mucosal acquisition, it can be hypothesized that potential differences among the variants at various times post acquisition are likely smaller. Thus, larger sample sizes would be needed to document a significant difference. Although we obtained our samples from one of the largest cohorts of injection drug users [58], there are still only a limited number of samples from individuals sampled prior to HIV-1 seroconversion. We did not seek samples from other cohort of injection drug users because of subject heterogeneity and viral subtype differences $[59,60]$. In context to the statistical analyses, it should be noted that we did not adjust for multiple comparisons. Clearly conservative adjustments for multiple comparisons would have rendered all findings statistically insignificant given the small sample sizes. Regardless, the observed significant differences are unlikely due random chance alone because of the similarity in the observed unique phenotypic characteristics among the earliest variants sampled from both sexually and IDU acquired viruses.

Another reason we may have failed to observe replication differences among the groups in our study is because we compared the envelope variants isolated prior to seroconversion to viruses sampled later in infection from unrelated subjects [5]. The limited variants that establish a systemic infection in a naive host may harbor a phenotype that favors its acquisition compared to the swarm present in the transmission source. This selection property, however, may not necessarily be significantly different among the acquired variants and unrelated chronic infection controls. It should be noted, however, that we examined envelope properties in the context of an infectious clone, which is different from most studies that use 293T derived single cycle virus pseudotypes [12,14,28,57]. Besides the fact that single cycle viruses cannot be used to examine replication in primary cells, $293 \mathrm{~T}$ as compared to peripheral blood mononuclear cell (PBMC) derived viruses often have different envelope density and glycans, which can influence receptor binding, neutralization and other properties $[47,61,62]$. Thus, peripheral blood mononuclear cell (PBMC) generated viruses have more physiologically relevant phenotypes compared to the 293T transfection derived virions. Although, it cannot be unequivocally stated that PBMC passage does not affect the virus phenotype, changes are generally less likely to occur in the short term cultures (maximum 7 days) used in our study. In addition, because all virus stocks were generated in a similar manner, changes induced by the short term PBMC passage should have affected the viruses from the 3 different phases of infection in an equivalent manner.

There are a number of limitations with our study. First, similar to all investigations of injection drug users, one can never be certain that the subjects acquired their infection through IDU. Even though individuals may report active IDU and have strong markers for this activity, such as co-infection with $\mathrm{HCV}$, there is no way to definitively exclude the possibility that they acquired their virus through sexual contact. Second, we only examined properties of the envelope glycoprotein quasispecies. It is quite possible that other viral genomic regions, such as gag, influence replication especially in MDDC - CD4+ T cell co-cultures [63,64]. Third, we did not isolate the T/F envelopes from the HIV RNA+/Absubjects. Although HIV-1 diversifies relatively quickly, there were likely minimal changes in the quasispecies isolated prior to seroconversion as opposed to the predicted T/F strains. In aggregate, from our studies, we 
can conclude that IDU acquired pre-seroconversion as compared to chronic phase infection virus envelope quasispecies when inserted into an isogenic backbone require higher CCR5 receptor levels, have lower fusion capacity, replicate less efficiently in MDDC-CD4+ T cell co-cultures, and confer enhanced IFN- $\alpha$ sensitivity.

\section{Conclusion}

To our knowledge, this is the first study that has extensively examined the envelope phenotypic properties of HIV-1 variants found among individuals who presumably acquired their infection through IDU. A strength of this study is that we sampled subjects prior to seroconversion, and thus we were able to characterize the earliest virus swarm after acquisition, albeit not the predicted $\mathrm{T} / \mathrm{F}$ variants. While previous genotypic studies suggest that limited number of variants, although likely greater than the number acquired across mucosal surfaces, establish a systemic infection in injection drug users, our phenotypic data suggest that these earliest envelopes have unique envelope properties compared to chronic infection variants. Phenotypic similarities among mucosally and IDU acquired viruses, such as a requirement for high CCR5 receptor levels, suggest that the different modes of acquisition share similar biological mechanisms that dictate the types of variants that establish a systemic infection in a naïve individual.

\section{Methods}

\section{Subjects}

All subjects examined were from the AIDS Linked to the IntraVenous Experience (ALIVE) cohort, which follows HIV-1 uninfected and HIV-1 infected injection drug users in Baltimore, Maryland through semiannual visits [58]. Estimated acquisition interval was based on serological testing of longitudinal samples. Newly seropositive subjects' previously seronegative sample was tested for HIV-1 RNA with a pooled viral load assay as previously described to identify the HIV-1+/Ab- individuals $[65,66]$. The seroconversion date was estimated as the midpoint between the last HIV-1 seronegative visit and the day the first HIV-1 seropositive sample was obtained. All subjects sampled within a year (early) and around two to three after seroconversion (chronic) have been described previously [34]. The study was approved by human subjects review boards at Johns Hopkins University, Bloomberg School of Public Health, and Brigham and Women's Hospital; all participants provided informed written consent.

\section{Envelope amplification and analysis}

For all subjects, HIV-1 RNA was isolated from around $100 \mathrm{ul}$ of the serum samples, and RT-PCR was used to amplify a library of full-length envelope genes using previously described primers and amplification conditions [6]. For each subject, a minimum of 4 independent PCRs were pooled to generate a library of envelopes from each serum sample. Pooled envelope amplifications were inserted into linearized pCMV-NL4-3-PBS $\rightarrow$ LTR $\Delta$ Gp160 plasmid using yeast gap-repair homologous recombination as previously described $[34,38]$. Clone pools were transfected into HEK293T cells and culture supernatants were passaged on PBMC for a maximum of 7 days. In contrast to our previous study [34], all virus stocks were generated from a combination of supernatants obtained from 3 independent cloning attempts from 3 different PBMC cultures. The number of infectious particles (IP) was estimated on TZM-bl cells as previously described $[25,67]$.

Twelve individual full-length envelopes were isolated and sequenced from each subject's clones. All unique sequences reported in this publication have been submitted to Genbank (accession numbers KP171242 - KP171495). Average of pairwise distances was used to estimate genetic diversity. Divergence was estimated as the average distance from the subject's sequences to the estimated ancestor as described previously [21]. Amino acid lengths and number of predicted N-linked glycosylation sites (PNGS) of different envelope segments were analyzed as previously described [21].

\section{Inhibitor sensitivity}

TZM-bl, U87/CD4/CXCR4 and U87/CD4/CCR5 cells, Enfuvirtide, Maraviroc, and CD4 B4 monoclonal antibody were obtained through Research and Reference Reagent Program, Division of AIDS, NIAID, NIH [68-70]. Infection of TZM-bl cells in the absence and presence of twofold serial dilution of the inhibitor was used to estimate the $50 \%$ inhibitory concentration $\left(\mathrm{IC}_{50}\right)$ as previously described [30]. All reported $\mathrm{IC}_{50} \mathrm{~s}$ are mean estimates from a minimum of 3 independent assays. Coreceptor usage was determined by monitoring p24 production in U87/CD4/ CXCR4 and U87/CD4/CCR5 cells infected with 500 IP of each virus supernatant.

\section{Primary cells and infections}

PBMCs were isolated from HIV-1 negative blood donation volunteer's buffy coats using Ficoll Hypaque density centrifugation. Monocytes were isolated from PBMCs using the percoll gradient method [71]. Primary human immature DCs were derived from monocytes, as described previously [72]. Briefly, monocytes were cultured in RPMI/10\% FBS containing recombinant human GM-CSF $(0.5 \mu \mathrm{g} / \mathrm{ml}$; Leukine, Berlex $)$ and recombinant human IL-4, $100 \mathrm{U} / \mathrm{ml}$ (Peprotech) for 6 days. Mature DCs were obtained by culturing immature DCs at day six of culture for two additional days in the presence of $100 \mathrm{ng} / \mathrm{ml}$ of ultra-pure E. coli LPS (Sigma). Primary human CD4+ and 
CD8 + T cells were positively isolated from monocyte depleted PBMCs using antibody conjugated magnetic beads (Miltenyi Biotech) according to manufacturer's instructions. CD4+ T cells were activated with $2 \%$ phytohaemagglutinin (PHA) and $20 \mathrm{ug} / \mathrm{ml}$ recombinant human IL-2 (r-IL-2) for 2 days.

Around $2 \times 10^{6} \mathrm{CD} 4+\mathrm{T}$ cells were exposed to 1,000 infectious particles in the presence of $20 \mathrm{U} / \mathrm{ml}$ diethylaminoethyl (DEAE) Dextran. After two hours, cultures were washed a minimum of three times to remove unbound virus. Around $0.5 \times 10^{6}$ immature or mature DCs were independently exposed to 1,000 infectious particles. After three hours, DC cultures were washed a minimum of three times to remove unbound virus. Virus exposed DC infections were cultured either with or without autologous activated CD4+ T cells. Infectious virus concentration was estimated by infecting $1 \times 10^{4}$ TZM-bl cells with 4 to 8 serial two-fold dilutions of supernatant culture starting at $50 \mathrm{ul}$ (Additional file 1: Figures S6 and S7 for representative examples). All infections were done in triplicate in a 96 well format. Two days post-infection, TZM-bls were examined for beta-galactosidase production using Galacto-Light Plus System (Applied Biosystems). Virus stock dilutions in the non-linear range of the TZM-bl assay were discarded. A linear interpolated curve of the relative light units (RLUs) versus supernatant dilution was used to estimate RLU/ul. The AUC was generated from the plot of RLU/ul versus days post infection. Primary cell infections were repeated a minimum of 4 times with cells from 4 different buffy coats. Culture supernatants were also assessed for p24 antigen content using an in house assay as previously described [73].

\section{Replication in CD4+ and binding to CD8+ T cells expressing high $\alpha 4 \beta 7$ integrin levels}

Gut homing receptor, $\alpha 4 \beta 7$, usage was examined as previously described [49]. Briefly, both CD8+ and CD4+ T cells were activated with PHA, r-IL-2, and retinoic acid (RA) for 6 days. Only cells confirmed to have enhanced $\alpha 4 \beta 7$ expression as determined by binding of phycoerythrin (PE) conjugated anti-mouse integrin $\beta 7$ antibody (clone FIB27) (BioLegend) were used in the subsequent assays. Around $1 \times 10^{6} \mathrm{CD} 8+$ and $\mathrm{CD} 4+\mathrm{T}$ cells were exposed to $1 \times 10^{5}$ infectious virus for 1 hour at $4^{\circ} \mathrm{C}$ in HEPES-buffered saline with $100 \mu \mathrm{M} \mathrm{CaCl}_{2}$ and $1 \mathrm{mM}$ $\mathrm{MnCl}_{2}$. Cells were washed a minimum of 3 times to remove unbound virus. RNA was isolated from the CD8+ $\mathrm{T}$ cells using the QIAAMP Viral RNA kit (QIAGEN). HIV-1 copies were quantified using quantitative RT-PCR using previously described methods $[74,75]$. The CD4+ T cells were incubated at $37^{\circ} \mathrm{C} 5 \% \mathrm{CO}_{2}$, and the infectious virus concentration in the culture supernatants was measured after 3 days as detailed above.

\section{Replication in the presence of IFN- $a$}

CD4+ T cells were pre-treated with $1000 \mathrm{U} / \mathrm{ml}$ IFN-2 $\alpha$ (PBL Assay Science) for 4 hours. Around $2 \times 10^{5}$ pre-treated and untreated CD4+ T cells were exposed to $2 \times 10^{3}$ infectious virus for $2-3$ hours. Following exposure, cells were washed and re-plated in the presence or absence of IFN- $\alpha$ along with $20 \mathrm{U} / \mathrm{ml} \mathrm{r-IL-2.} \mathrm{After}$ 7 days, supernatants were removed, and TZM-bl cells were exposed to 4 different supernatant dilutions. Importantly, we confirmed that TZM-bl infections were not affected by the presence of IFN- $\alpha$ (Additional file 1: Figure S7). The RLUs generated from the TZM-bl infections were measured 2 days after exposure, and the RLU versus supernatant dilution plot was used to estimate an AUC for each virus in the presence and absence of IFN- $\alpha$. The \% IFN- $\alpha$ resistance was estimated from the ratio of AUC in the presence compared to the absence of IFN- $\alpha$.

\section{Statistical analysis}

Summary characteristics were compared among the HIV $\mathrm{RNA}+/ \mathrm{Ab}$ - envelopes to the other group of viruses using the Wilcoxon rank-sum test. Longitudinal comparisons among the early and chronic samples were done using the matched pair Wilcoxon rank-sum test. All p-values were based on a two-sided test. Initially, comparisons were done independently for primary cells obtained from different donors. Linear regression models were used for the aggregate comparisons among the three groups in the primary cells from four different donors. The differences between chronic and early values were the outcome for the longitudinal analysis. Linear regressions models of the log transformed values were adjusted for the four different donors and considered an interaction between the three groups and the origin of the primary cells. The correlation between observations from the same donor was negligible, and adjusting for this via generalized estimating equations (GEE) had no impact on the results. Nonparametric bootstrapping with 1999 bootstrapped samples was used to obtain $95 \%$ confidence intervals. All statistical analyses were done with either Intercooled Stata version 8.0 (Stata Corporation, College Station, TX) or R 2.15 (r-project.org).

\section{Additional file}

Additional file 1: Figure S1. Infectivity (I) and replication kinetics are not significantly different among recombinant viruses with envelopes amplified using either single genome amplification (SGA) or multiple bulk PCR. Figure S2. Virus replication kinetics are similar as measured by the detection of p24 and infectious virus on TZM-bl cells. Figure S3. Virus replication varies in CD4+ T cells from different donor. Figure S4. Virus replication varies in mature MDDC - CD4+ T co-cultures with cells from different donors. Figure S5. Virus replication varies in immature MDDC - CD4+ T co-cultures with cells from different donors. Figure S6. Virus replication in the presence or absence of IFN-a in CD4+ T cells from different donors. 


\section{Competing interests}

The authors declare that they have no competing interests.

\section{Authors' contributions}

BE constructed the viruses, conducted the replication and binding experiments and contributed to manuscript development. OG conducted the interferon resistance testing. LFW did the statistical analysis. OL, GK, and SM were clinical site investigators, contributed to data interpretation and manuscript development. MS designed the study, oversaw clinical and laboratory aspects of the study, analyzed and interpreted the data, and contributed to the manuscript development. All authors read and approved the final manuscript.

\section{Acknowledgements}

We thank all the subjects who have contributed samples for these studies as part of the ALIVE cohort. This study was supported by NIH grants Al077473 (MS) and Al102774 (MS). The funders had no role in study design, data collection and analysis, decision to publish, or preparation of the manuscript.

\section{Author details}

${ }^{1}$ Boston University School of Medicine, Boston, MA, USA. ${ }^{2}$ Boston University School of Public Health, Boston, MA, USA. ${ }^{3}$ Johns Hopkins University School of Medicine, Baltimore, MD, USA. ${ }^{4}$ Division of Intramural Research, National Institute of Allergy and Infectious Diseases, National Institutes of Health, Bethesda, MD, USA. ${ }^{5}$ Johns Hopkins University, Bloomberg School of Public Health, Baltimore, MD, USA.

Received: 22 May 2014 Accepted: 8 November 2014 Published online: 28 November 2014

\section{References}

1. Sagar M, Kirkegaard E, Long EM, Celum C, Buchbinder S, Daar ES, Overbaugh J: Human immunodeficiency virus type 1 (HIV-1) diversity at time of infection is not restricted to certain risk groups or specific HIV-1 subtypes. $J$ Virol 2004, 78:7279-7283.

2. Bar KJ, Li H, Chamberland A, Tremblay C, Routy JP, Grayson T, Sun C, Wang S, Learn GH, Morgan CJ, Schumacher JE, Haynes BF, Keele BF, Hahn BH, Shaw GM: Wide variation in the multiplicity of HIV-1 infection among injection drug users. J Virol 2010, 84:6241-6247.

3. Masharsky A, Dukhovlinova E, Verevochkin S, Toussova O, Skochilov R, Anderson J, Hoffman I, Cohen M, Swanstrom R, Kozlov AP: A significant transmission bottleneck among newly and recently HIV-1 infected injection drug users in St. Petersburg, Russia. J Infect Dis 2010, in press.

4. Markham RB, Wang WC, Weisstein AE, Wang Z, Munoz A, Templeton A, Margolick J, Vlahov D, Quinn T, Farzadegan H, Yu XF: Patterns of HIV-1 evolution in individuals with differing rates of CD4 T cell decline. Proc Natl Acad Sci U S A 1998, 95:12568-12573.

5. Pena-Cruz V, Etemad B, Chatziandreou N, Nyein PH, Stock S, Reynolds SJ, Laeyendecker O, Serwadda D, Gray RH, Lee S, Quinn TC, Sagar M: HIV-1 envelope replication and a4 $\beta 7$ utilization among newly infected subjects and their corresponding heterosexual partners. Retrovirology 2013, 10:162.

6. Keele BF, Giorgi EE, Salazar-Gonzalez JF, Decker JM, Pham KT, Salazar MG, Sun C, Grayson T, Wang S, Li H, Wei X, Jiang C, Kirchherr JL, Gao F, Anderson JA, Ping LH, Swanstrom R, Tomaras GD, Blattner WA, Goepfert PA, Kilby JM, Saag MS, Delwart EL, Busch MP, Cohen MS, Montefiori DC, Haynes BF, Gaschen B, Athreya GS, Lee HY: Identification and characterization of transmitted and early founder virus envelopes in primary HIV-1 infection. Proc Natl Acad Sci U S A 2008, 105:7552-7557.

7. Li H, Bar KJ, Wang S, Decker JM, Chen Y, Sun C, Salazar-Gonzalez JF, Salazar MG, Learn GH, Morgan CJ, Schumacher JE, Hraber P, Giorgi EE, Bhattacharya T, Korber BT, Perelson AS, Eron JJ, Cohen MS, Hicks CB, Haynes BF, Markowitz M, Keele BF, Hahn BH, Shaw GM: High multiplicity infection by HIV-1 in men who have sex with men. PLoS Pathog 2010, 6:e1000890.

8. Haaland RE, Hawkins PA, Salazar-Gonzalez J, Johnson A, Tichacek A, Karita E, Manigart O, Mulenga J, Keele BF, Shaw GM, Hahn BH, Allen SA, Derdeyn CA, Hunter E: Inflammatory genital infections mitigate a severe genetic bottleneck in heterosexual transmission of subtype A and C HIV-1. PLOS Pathog 2009, 5:e1000274.

9. Kearney M, Maldarelli F, Shao W, Margolick JB, Daar ES, Mellors JW, Rao V, Coffin JM, Palmer S: Human immunodeficiency virus type 1 population genetics and adaptation in newly infected individuals. J Virol 2009, 83:2715-2727.
10. Long EM, Martin HL Jr, Kreiss JK, Rainwater SM, Lavreys L, Jackson DJ, Rakwar J, Mandaliya K, Overbaugh J: Gender differences in HIV-1 diversity at time of infection. Nat Med 2000, 6:71-75

11. Parrish NF, Gao F, Li H, Giorgi EE, Barbian HJ, Parrish EH, Zajic L, lyer SS, Decker JM, Kumar A, Hora B, Berg A, Cai F, Hopper J, Denny TN, Ding H, Ochsenbauer C, Kappes JC, Galimidi RP, West AP Jr, Bjorkman PJ, Wilen CB, Doms RW, O'Brien M, Bhardwaj N, Borrow P, Haynes BF, Muldoon M, Theiler JP, Korber B: Phenotypic properties of transmitted founder HIV-1. ProC Natl Acad Sci U S A 2013, 110:6626-6633.

12. Parrish N, Wilen C, Banks L, lyer S, Pfaff J, Salazar-Gonzalez J, Salazar MG, Decker JM, Parrish E, Berg A, Hopper J, Hora B, Kumar A, Mahlokozera T, Yuan S, Coleman C, Vermeulen M, Ding H, Ochsenbauer C, Tilton JC, Permar S, Kappes JC, Betts M, Busch M, Gao F, Montefiori D, Haynes B, Shaw GM, Hahn BH, Doms RW: Transmitted/founder and chronic subtype C HIV-1 use CD4 and CCR5 receptors with equal efficiency and are not inhibited by blocking the integrin a4b7. PLOS Pathog 2012,8

13. Li M, Salazar-Gonzalez JF, Derdeyn CA, Morris L, Williamson C, Robinson JE, Decker JM, Li Y, Salazar MG, Polonis VR, Mlisana K, Karim SA, Hong K, Greene KM, Bilska M, Zhou J, Allen S, Chomba E, Mulenga J, Vwalika C, Gao F, Zhang M, Korber BT, Hunter E, Hahn BH, Montefiori DC: Genetic and neutralization properties of subtype $C$ human immunodeficiency virus type 1 molecular env clones from acute and early heterosexually acquired infections in Southern Africa. J Virol 2006, 80:11776-11790.

14. Isaacman-Beck J, Hermann EA, Yi Y, Ratcliffe SJ, Mulenga J, Allen S, Hunter E, Derdeyn CA, Collman RG: Heterosexual transmission of human immunodeficiency virus type 1 subtype C: Macrophage tropism, alternative coreceptor use, and the molecular anatomy of CCR5 utilization. J Virol 2009, 83:8208-8220.

15. Powers KA, Poole C, Pettifor AE, Cohen MS: Rethinking the heterosexual infectivity of HIV-1: a systematic review and meta-analysis. Lancet Infect Dis 2008, 8:553-563.

16. Zhu T, Mo H, Wang N, Nam DS, Cao Y, Koup RA, Ho DD: Genotypic and phenotypic characterization of HIV-1 patients with primary infection. Science 1993, 261:1179-1181.

17. Sagar M, Lavreys L, Baeten JM, Richardson BA, Mandaliya K, Chohan BH, Kreiss JK, Overbaugh J: Infection with multiple human immunodeficiency virus type 1 variants is associated with faster disease progression. J Virol 2003, 77:12921-12926.

18. Sagar M, Lavreys L, Baeten JM, Richardson BA, Mandaliya K, Ndinya-Achola JO, Kreiss JK, Overbaugh J: Identification of modifiable factors that affect the genetic diversity of the transmitted HIV-1 population. AIDS 2004, 18:615-619.

19. Sagar M: HIV-1 transmission biology: selection and characteristics of infecting viruses. J Infect Dis 2010, 202(Suppl 2):S289-296.

20. Derdeyn CA, Decker JM, Bibollet-Ruche F, Mokili JL, Muldoon M, Denham SA, Heil ML, Kasolo F, Musonda R, Hahn BH, Shaw GM, Korber BT, Allen S, Hunter E: Envelope-constrained neutralization-sensitive HIV-1 after heterosexual transmission. Science 2004, 303:2019-2022.

21. Sagar M, Laeyendecker O, Lee S, Gamiel J, Wawer MJ, Gray RH, Serwadda D, Sewankambo NK, Shepherd JC, Toma J, Huang W, Quinn TC: Selection of HIV variants with signature genotypic characteristics during heterosexual transmission. J Infect Dis 2009, 199:580-589.

22. Redd AD, Collinson-Streng AN, Chatziandreou N, Mullis CE, Laeyendecker $\mathrm{O}$, Martens C, Ricklefs S, Kiwanuka N, Nyein PH, Lutalo T, Grabowski MK, Kong X, Manucci J, Sewankambo N, Wawer MJ, Gray RH, Porcella SF, Fauci AS, Sagar M, Serwadda D, Quinn TC: Previously transmitted HIV-1 strains are preferentially selected during subsequent sexual transmissions. J Infect Dis 2012, 206:1433-1442.

23. Herbeck JT, Nickle DC, Learn GH, Gottlieb GS, Curlin ME, Heath L, Mullins $\mathrm{J}$ : Human immunodeficiency virus type 1 env evolves toward ancestral states upon transmission to a new host. J Virol 2006, 80:1637-1644

24. Chohan B, Lang D, Sagar M, Korber B, Lavreys L, Richardson B, Overbaugh J: Selection for human immunodeficiency virus type 1 envelope glycosylation variants with shorter V1-V2 loop sequences occurs during transmission of certain genetic subtypes and may impact viral RNA levels. J Virol 2005, 79:6528-6531.

25. Sagar M, Wu X, Lee S, Overbaugh J: HIV-1 V1-V2 envelope loop sequences expand and add glycosylation sites over the course of infection and these modifications affect antibody neutralization sensitivity. J Virol 2006, 80:9586-9598 
26. Curlin ME, Zioni R, Hawes SE, Liu Y, Deng W, Gottlieb GS, Zhu T, Mullins Jl: HIV-1 envelope subregion length variation during disease progression. PLOS Pathog 2010, 6:e1001228.

27. Frost SD, Liu Y, Pond SL, Chappey C, Wrin T, Petropoulos CJ, Little SJ, Richman DD: Characterization of human immunodeficiency virus type 1 (HIV-1) envelope variation and neutralizing antibody responses during transmission of HIV-1 subtype B. J Virol 2005, 79:6523-6527.

28. Wilen CB, Parrish NF, Pfaff JM, Decker JM, Henning EA, Haim H, Petersen JE, Wojcechowskyj JA, Sodroski J, Haynes BF, Montefiori DC, Tilton JC, Shaw GM, Hahn BH, Doms RW: Phenotypic and immunologic comparison of clade B transmitted/founder and chronic HIV-1 envelope glycoproteins. J Virol 2011, 85:8514-8527.

29. Boeras DI, Hraber PT, Hurlston M, Evans-Strickfaden T, Bhattacharya T, Giorgi EE, Mulenga J, Karita E, Korber BT, Allen S, Hart CE, Derdeyn CA, Hunter E: Role of donor genital tract HIV-1 diversity in the transmission bottleneck. Proc Natl Acad Sci U S A 2011, 108:E1156-1163.

30. Etemad B, Fellows A, Kwambana B, Kamat A, Feng Y, Lee S, Sagar M: Human immunodeficiency virus type $1 \mathrm{~V} 1$-to-V5 envelope variants from the chronic phase of infection use CCR5 and fuse more efficiently than those from early after infection. J Virol 2009, 83:9694-9708.

31. Redd AD, Laeyendecker O, Kong X, Kiwanuka N, Lutalo T, Huang W, Gray RH, Wawer MJ, Serwadda D, Eshleman SH, Quinn TC: Efficiency of CCR5 coreceptor utilization by the HIV quasispecies increases over time, but is not associated with disease progression. AIDS Res Hum Retroviruses 2011, 28:289-294.

32. Koning FA, Kwa D, Boeser-Nunnink B, Dekker J, Vingerhoed J, Hiemstra H, Schuitemaker H: Decreasing sensitivity to RANTES (regulated on activation normally T cell-expressed and -secreted) neutralization of CC chemokine receptor 5-using, non-syncytium-inducing virus variants in the course of human immunodeficiency virus type 1 infection. J Infect Dis 2003, 188:864-872.

33. Parker ZF, lyer SS, Wilen CB, Parrish NF, Chikere KC, Lee FH, Didigu CA, Berro R, Klasse PJ, Lee B, Moore JP, Shaw GM, Hahn BH, Doms RW: Transmitted/ founder and chronic HIV-1 envelope proteins are distinguished by differential utilization of CCR5. J Virol 2013, 87:2401-2411.

34. Chatziandreou N, Arauz AB, Freitas I, Nyein PH, Fenton G, Mehta SH, Kirk GD Sagar M: Sensitivity changes over the course of infection increases the likelihood of resistance against fusion but not CCR5 receptor blockers. AIDS Res Hum Retroviruses 2012, 28:1584-1593.

35. Fenton-May AE, Dibben O, Emmerich T, Ding H, Pfafferott K, Aasa-Chapman MM, Pellegrino P, Williams I, Cohen MS, Gao F, Shaw GM, Hahn BH, Ochsenbauer C, Kappes JC, Borrow P: Relative resistance of HIV-1 founder viruses to control by interferon-alpha. Retrovirology 2013, 10:146.

36. Domingo E, Sheldon J, Perales C: Viral quasispecies evolution. Microbiol Mol Biol Rev 2012, 76:159-216.

37. McClure $P$, Curran $R$, Boneham S, Ball JK: A polymerase chain reaction method for the amplification of full-length envelope genes of HIV-1 from DNA samples containing single molecules of HIV-1 provirus. J Virol Methods 2000, 88:73-80.

38. Dudley DM, Gao Y, Nelson KN, Henry KR, Nankya I, Gibson RM, Arts EJ: A novel yeast-based recombination method to clone and propagate diverse HIV-1 isolates. Biotechniques 2009, 46:458-467.

39. King DF, Siddiqui AA, Buffa V, Fischetti L, Gao Y, Stieh D, McKay PF, Rogers P, Ochsenbauer C, Kappes JC, Arts EJ, Shattock RJ: Mucosal tissue tropism and dissemination of HIV-1 subtype B acute envelope-expressing chimeric virus. J Virol 2013, 87:890-899.

40. Salazar-Gonzalez JF, Bailes E, Pham KT, Salazar MG, Guffey MB, Keele BF, Derdeyn CA, Farmer P, Hunter E, Allen S, Manigart O, Mulenga J, Anderson JA, Swanstrom R, Haynes BF, Athreya GS, Korber BT, Sharp PM, Shaw GM, Hahn BH: Deciphering human immunodeficiency virus type 1 transmission and early envelope diversification by single-genome amplification and sequencing. J Virol 2008, 82:3952-3970.

41. Tsibris AM, Sagar M, Gulick RM, Su Z, Hughes M, Greaves W, Subramanian M, Flexner C, Giguel F, Leopold KE, Coakley E, Kuritzkes DR: In vivo emergence of vicriviroc resistance in a human immunodeficiency virus type 1 subtype C-infected subject. J Virol 2008, 82:8210-8214.

42. Steinman RM, Granelli-Piperno A, Pope M, Trumpfheller C, Ignatius R, Arrode $G$, Racz P, Tenner-Racz K: The interaction of immunodeficiency viruses with dendritic cells. Curr Top Microbiol Immunol 2003, 276:1-30.

43. Haase AT: Targeting early infection to prevent HIV-1 mucosal transmission. Nature 2010, 464:217-223.
44. Geijtenbeek TB, Kwon DS, Torensma R, van Vliet SJ, van Duijnhoven GC, Middel J, Cornelissen IL, Nottet HS, KewalRamani VN, Littman DR, Figdor CG, van Kooyk Y: DC-SIGN, a dendritic cell-specific HIV-1-binding protein that enhances trans-infection of T cells. Cell 2000, 100:587-597.

45. Mehandru S, Poles MA, Tenner-Racz K, Horowitz A, Hurley A, Hogan C, Boden D, Racz P, Markowitz M: Primary HIV-1 infection is associated with preferential depletion of CD4+ T lymphocytes from effector sites in the gastrointestinal tract. J Exp Med 2004, 200:761-770.

46. Arthos J, Cicala C, Martinelli E, Macleod K, Van Ryk D, Wei D, Xiao Z, Veenstra TD, Conrad TP, Lempicki RA, McLaughlin S, Pascuccio M, Gopaul R, McNally J, Cruz CC, Censoplano N, Chung E, Reitano KN, Kottilil S, Goode DJ, Fauci AS: HIV-1 envelope protein binds to and signals through integrin alpha4beta7, the gut mucosal homing receptor for peripheral T cells. Nat Immunol 2008, 9:301-309.

47. Nawaz F, Cicala C, Van Ryk D, Block KE, Jelicic K, McNally JP, Ogundare O, Pascuccio M, Patel N, Wei D, Fauci AS, Arthos J: The genotype of early-transmitting HIV gp120s promotes alpha (4) beta(7)-reactivity, revealing alpha (4) beta(7) +/CD4+ T cells as key targets in mucosal transmission. PLoS Pathog 2011, 7:e1001301.

48. Cicala C, Martinelli E, McNally JP, Goode DJ, Gopaul R, Hiatt J, Jelicic K, Kottilil S, Macleod K, O'Shea A, Patel N, Van Ryk D, Wei D, Pascuccio M, Yi L, McKinnon L, Izulla P, Kimani J, Kaul R, Fauci AS, Arthos J: The integrin alpha4beta7 forms a complex with cell-surface CD4 and defines a T-cell subset that is highly susceptible to infection by HIV-1. Proc Natl Acad Sci US A 2009, 106:20877-20882.

49. Etemad B, Gonzalez OA, McDonough S, Pena-Cruz V, Sagar M: Early infection HIV-1 envelope V1-V2 genotypes do not enhance binding or replication in cells expressing high levels of alpha4beta7 integrin. J Acquir Immune Defic Syndr 2013, 64:249-253.

50. Li Q, Estes JD, Schlievert PM, Duan L, Brosnahan AJ, Southern PJ, Reilly CS, Peterson ML, Schultz-Darken N, Brunner KG, Nephew KR, Pambuccian S, Lifson JD, Carlis JV, Haase AT: Glycerol monolaurate prevents mucosal SIV transmission. Nature 2009, 458:1034-1038.

51. Shankarappa R, Margolick JB, Gange SJ, Rodrigo AG, Upchurch D, Farzadegan H, Gupta P, Rinaldo CR, Learn GH, He X, Huang XL, Mullins Jl: Consistent viral evolutionary changes associated with the progression of human immunodeficiency virus type 1 infection. J Virol 1999, 73:10489-10502.

52. Reeves JD, Gallo SA, Ahmad N, Miamidian JL, Harvey PE, Sharron M, Pohlmann S, Sfakianos JN, Derdeyn CA, Blumenthal R, Hunter E, Doms RW: Sensitivity of HIV-1 to entry inhibitors correlates with envelope/coreceptor affinity, receptor density, and fusion kinetics. Proc Natl Acad Sci U S A 2002, 99:16249-16254.

53. Lobritz MA, Marozsan AJ, Troyer RM, Arts EJ: Natural variation in the V3 crown of human immunodeficiency virus type 1 affects replicative fitness and entry inhibitor sensitivity. J Virol 2007, 81:8258-8269.

54. Herold M, Meise U, Gunther V, Rossler H, Zangerle R: Serum concentrations of circulating endogenous granulocyte-macrophage colony-stimulating factor in HIV-1-seropositive injecting drug users. Presse Med 1994, 23:1854-1858.

55. Ownby RL, Kumar AM, Benny Fernandez J, Moleon-Borodowsky I, Gonzalez L, Eisdorfer S, Waldrop-Valverde D, Kumar M: Tumor necrosis factor-alpha levels in HIV-1 seropositive injecting drug users. J Neuroimmune Pharmacol 2009, 4:350-358.

56. Iyer SS, Fenton-May AE, Smith AG, Zhang W, Kappes JC, Gao F, Bibollet-Ruche F, Hui L, Shaw GM, Borrow P, Hahn B: Characterizing the IFN-a Resistance of Transmitted Founder HIV-1. In Boston: Conference on Retroviruses and Opportunistic Infections; 2014.

57. Alexander M, Lynch R, Mulenga J, Allen S, Derdeyn CA, Hunter E: Donor and recipient envs from heterosexual human immunodeficiency virus subtype $\mathrm{C}$ transmission pairs require high receptor levels for entry. J Virol 2010, 84:4100-4104.

58. Vlahov D, Graham N, Hoover D, Flynn C, Bartlett JG, Margolick JB, Lyles CM, Nelson KE, Smith D, Holmberg S, Farzadegan H: Prognostic indicators for AIDS and infectious disease death in HIV-infected injection drug users: plasma viral load and CD4+ cell count. JAMA 1998, 279:35-40.

59. Beyrer C, Baral S, Shaboltas A, Dukhovlinova E, Masharsky A, Verevochkin S, Latkin C, Heimer R, Hoffman I, Kozlov A: The feasibility of HIV vaccine efficacy trials among Russian injection drug users. Vaccine 2007, 25:7014-7016.

60. Routy JP, Vanhems P, Rouleau D, Tsoukas C, Lefebvre E, Cote P, LeBlanc R, Conway B, Alary M, Bruneau J, Sekaly RP: Comparison of clinical features of 
acute HIV-1 infection in patients infected sexually or through injection drug use. J Acquir Immune Defic Syndr 2000, 24:425-432.

61. Provine NM, Puryear WB, Wu X, Overbaugh J, Haigwood NL: The infectious molecular clone and pseudotyped virus models of human immunodeficiency virus type 1 exhibit significant differences in virion composition with only moderate differences in infectivity and inhibition sensitivity. J Virol 2009, 83:9002-9007.

62. Provine NM, Cortez V, Chohan V, Overbaugh J: The neutralization sensitivity of viruses representing human immunodeficiency virus type 1 variants of diverse subtypes from early in infection is dependent on producer cell, as well as characteristics of the specific antibody and envelope variant. Virology 2012, 427:25-33.

63. Hatch SC, Archer J, Gummuluru S: Glycosphingolipid composition of human immunodeficiency virus type 1 (HIV-1) particles is a crucial determinant for dendritic cell-mediated HIV-1 trans-infection. J Virol 2009, 83:3496-3506

64. Akiyama H, Miller C, Patel HV, Hatch SC, Archer J, Ramirez NP, Gummuluru S: Virus particle release from GSL-enriched microdomains is essential for dendritic cell-mediated capture and transfer of HIV-1 and henipavirus. $J$ Virol 2014, in press.

65. Wawer MJ, Gray RH, Sewankambo NK, Serwadda D, Li X, Laeyendecker O, Kiwanuka N, Kigozi G, Kiddugavu M, Lutalo T, Nalugoda F, Wabwire-Mangen F, Meehan MP, Quinn TC: Rates of HIV-1 transmission per coital act, by stage of HIV-1 infection, in Rakai, Uganda. J Infect Dis 2005, 191:1403-1409.

66. Kiwanuka N, Laeyendecker O, Quinn TC, Wawer MJ, Shepherd J, Robb M Kigozi G, Kagaayi J, Serwadda D, Makumbi FE, Reynolds SJ, Gray RH: HIV-1 subtypes and differences in heterosexual HIV transmission among HIV-discordant couples in Rakai, Uganda. AIDS 2009, 23:2479-2484

67. Kimpton J, Emerman M: Detection of replication-competent and pseudotyped human immunodeficiency virus with a sensitive cell line on the basis of activation of an integrated beta-galactosidase gene. J Virol 1992, 66:2232-2239.

68. Wei X, Decker JM, Liu H, Zhang Z, Arani RB, Kilby JM, Saag MS, Wu X, Shaw GM, Kappes JC: Emergence of resistant human immunodeficiency virus type 1 in patients receiving fusion inhibitor (T-20) monotherapy. Antimicrob Agents Chemother 2002, 46:1896-1905.

69. Bjorndal A, Deng H, Jansson M, Fiore JR, Colognesi C, Karlsson A, Albert J, Scarlatti G, Littman DR, Fenyo EM: Coreceptor usage of primary human immunodeficiency virus type 1 isolates varies according to biological phenotype. J Virol 1997, 71:7478-7487.

70. Wang CY, Sawyer LS, Murthy KK, Fang X, Walfield AM, Ye J, Wang JJ, Chen PD, Li ML, Salas MT, Shen M, Gauduin MC, Boyle RW, Koup RA, Montefiori DC, Mascola JR, Koff WC, Hanson CV: Postexposure immunoprophylaxis of primary isolates by an antibody to HIV receptor complex. Proc Natl Acad Sci U S A 1999, 96:10367-10372.

71. de Almeida MC, Silva AC, Barral A, Barral Netto M: A simple method for human peripheral blood monocyte isolation. Mem Inst Oswaldo Cruz 2000, 95:221-223.

72. Wiley RD, Gummuluru S: Immature dendritic cell-derived exosomes can mediate HIV-1 trans infection. Proc Natl Acad Sci U S A 2006, 103:738-743.

73. Sagar M, Akiyama H, Etemad B, Ramirez N, Freitas I, Gummuluru S: Transmembrane Domain membrane proximal external region but Not surface unit-directed broadly neutralizing HIV-1 antibodies Can restrict dendritic cell-mediated HIV-1 trans-infection. J Infect Dis 2012, 205:1248-1257.

74. Rousseau CM, Nduati RW, Richardson BA, John-Stewart GC, Mbori-Ngacha DA, Kreiss JK, Overbaugh J: Association of levels of HIV-1-infected breast milk cells and risk of mother-to-child transmission. J Infect Dis 2004, 190:1880-1888.

75. Rousseau CM, Nduati RW, Richardson BA, Steele MS, John-Stewart GC, Mbori-Ngacha DA, Kreiss JK, Overbaugh J: Longitudinal analysis of human immunodeficiency virus type 1 RNA in breast milk and of its relationship to infant infection and maternal disease. J Infect Dis 2003, 187:741-747.

doi:10.1186/s12977-014-0106-8

Cite this article as: Etemad et al:: Characterization of HIV-1 envelopes in acutely and chronically infected injection drug users. Retrovirology 2014 11:106

\section{Submit your next manuscript to BioMed Central and take full advantage of:}

- Convenient online submission

- Thorough peer review

- No space constraints or color figure charges

- Immediate publication on acceptance

- Inclusion in PubMed, CAS, Scopus and Google Scholar

- Research which is freely available for redistribution 